\title{
Assessment of musicians' awareness in terms dental hard damage tissues caused by playing wind instruments
}

\author{
Ocena świadomości muzyków w aspekcie uszkodzeń w obrębie tkanek \\ twardych zębów spowodowanych grą na instrumentach dętych
}

\author{
Kamila Martyna Wróbel-Bednarz', Elżbieta Ktosowska², Agnieszka Drożdżyńska², \\ Aleksandra Ceglarska ${ }^{2}$, Rafat Korzeniewski², Daniel Surowiecki ${ }^{1}$ \\ ${ }^{1}$ Katedra Protetyki Stomatologicznej, Warszawski Uniwersytet Medyczny \\ Department of Prosthodontics, Medical University of Warsaw, Poland \\ Kierownik: prof. dr. hab. n. med. Elżbieta Mierzwińska-Nastalska \\ ${ }^{2}$ Studenckie Koło Naukowe przy Katedrze Protetyki Stomatologicznej, Warszawski Uniwersytet Medyczny \\ Students' Research Group at the Department of Prosthodontics, Medical University of Warsaw, Poland
}

KEY WORDS:

mouthguards, wind instruments, tissue injuries

\section{Summary}

Introduction. Playing on the wind instruments can cause injuries in the stomatognathic system. For this reason, dentists are witnessing an increasing number of patients who experience cranofacial problems arising from playing wind instruments. Prophylaxis and regular dental visits may help prevent these health problems.

Aim of the study. To assess awareness of mouthguards usage among windinstruments musicians and the frequency of occurrence of teeth damage in this study group.

Material and methods. A survey by means of a questionnaire consisting of fifty questions was conducted, addressed to people who play wind instruments, via thematic internet fora and interest groups in Poland and abroad. The study group consisted of 1067 people, including 370 women (35\%) and 697 men (65\%) aged 10 to 80 years. The mean age was 23 years. Musicians were divided into two groups depending on the type of instrument: woodwind (470 people) and brass (597 people).
HASŁA INDEKSOWE:

ochraniacze wewnątrzustne, instrumenty dęte, uszkodzenia tkanek

\section{Streszczenie}

Wprowadzenie. Gra na instrumentach dętych może wplywać na rozwój zmian w obrębie uktadu stomatognatycznego. Z tego powodu dentyści obserwuja wzrastajaca liczba pacjentów doświadczajacych problemów w obrębie twarzoczaszki, powstatych $w$ wyniku gry na instrumencie dętym. Poprzez profilaktyke i regularne wizyty u dentysty możliwe jest zapobieganie powyższym problemom zdrowotnym u muzyków.

Cel pracy. Ocena poziomu świadomości stosowania ochraniaczy wewnątrzustnych wśród muzyków grajacych na instrumentach dętych oraz ocena częstości wystepowania uszkodzeń w obrębie zębów w grupie badanej.

Material i metody. Przeprowadzono ankietę składajaca się z 50 pytań, kierowana do osób grajacych na instrumentach dętych poprzez tematyczne fora internetowe oraz grupy zainteresowań w Polsce i za granica. Grupę badana stanowito 1067 osób w tym 370 kobiet (35\%) i 697 mężczyzn (65\%) w wieku od 10 do 80 lat. Mediana wieku wynosiła 23 lat. Muzyków podzielono na 
Results. As many as $27 \%$ of respondents reported excessive tooth mobility. About 17\% of respondents reported excessive attrition with prevalence of women playing wind instruments ( $p$ $=0.02)$ and professional musicians $(p=0.01)$. Only 2\% of respondents used mouthguards when they played. $35.61 \%$ of respondents visited the dentist regularly every six months.

Conclusions. Musicians playing wind instruments constitute a group requiring increase of the level of awareness in terms of the damage risk and the prevention of stomatognathic system. Knowledge of dentists and hygienists regarding the prevention and treatment of this specific population plays a very important role, with particular emphasis on proper hygiene of the mouth and the instrument, and indications for the mouthguard usage.

\section{Introduction}

Nowadays, interest in classical music is increasing, and concerts in philharmonic halls are becoming more and more popular. It is also an important element of the cultural education of children in schools. Symphonic music is an essential part of the lives a significant number of people around the world. For this reason, the number of people learning how to play musical instruments is also increasing. Some of them choose the music path as their future career. Many musicians start music education in early childhood. Music classes take place at regular intervals, several hours a week. Playing wind instruments can affect the development of changes within the stomatognathic system. For this reason, dentists are observing an increasing number of patients experiencing faciocranial problems in consequence of playing a wind dwie grupy w zależności od rodzaju instrumentu: drewniany (470 osób) i blaszany (597 osób).

Wyniki. Aż 27\% respondentów zgłaszało nadmierna ruchomość zębów. Nadmierna atrycje ogótem zgłaszało około $17 \%$ ankietowanych częściej byty to kobiety grajace na instrumencie detym $(p=0,02)$ oraz muzycy zawodowi $(p=0,01)$. Tylko 2\% ankietowanych używało ochraniaczy wewnatrzustnych podczas gry na instrumencie dętym. Wizyty u lekarza stomatologa regularnie co 6 miesięcy odbywato 35,61\% osób.

Wnioski. Muzycy grajacy na instrumentach dętych sa grupa pacjentów wymagajaca zwiększenia poziomu świadomości $w$ aspekcie ryzyka powstawania uszkodzeń w obrębie uktadu stomatognatycznego oraz ich zapobiegania. Ważna role odgrywa wiedza lekarzy dentystów i higienistek odnośnie profilaktyki i leczenia tej grupy pacjentów ze szczególnym uwzględnieniem odpowiedniej higieny jamy ustnej oraz instrumentu, jak również wskazań do zastosowania ochraniacza wewnątrzustnego.

\section{Wstęp}

W dzisiejszych czasach wzrasta zainteresowanie muzyką klasyczną, a koncerty w filharmonii cieszą się coraz większą popularnością. Jest to również ważny element edukacji kulturalnej dzieci w szkołach. Muzyka symfoniczna jest istotną częścią życia znacznej populacji osób na całym świecie. $Z$ tego powodu wzrasta również liczba osób uczących się gry na instrumentach muzycznych. Część z nich wybiera ścieżkę muzyczną jako swój przyszły zawód. Wielu muzyków zaczyna edukację muzyczną we wczesnym dzieciństwie. Próby odbywają się w regularnych odstępach czasu, kilka godzin tygodniowo. Gra na instrumentach dętych może wpływać na rozwój zmian w obrębie układu stomatognatycznego. $\mathrm{Z}$ tego powodu lekarze dentyści obserwują wzrastającą liczbą pacjentów doświadczających problemów 


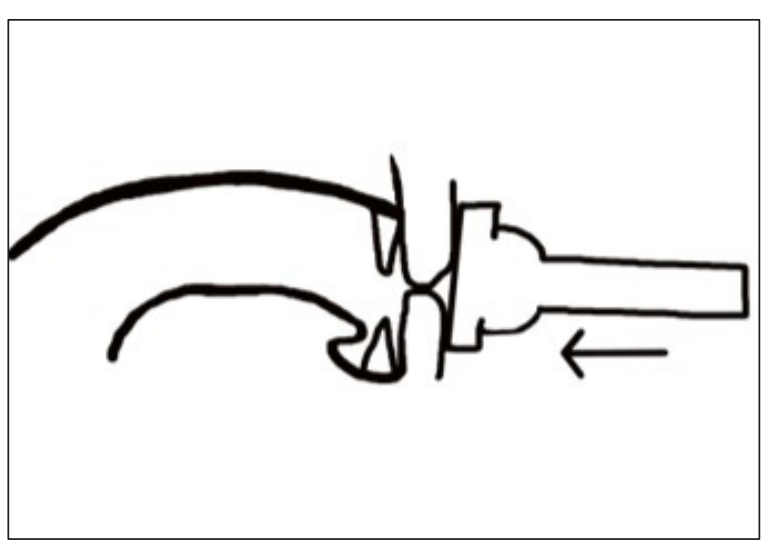

Fig. 1. Mouthpiece insertion method: brass instruments.

Ryc. 1. Metoda przyłożenia ustnika: instrumenty dęte blaszane.

instrument. ${ }^{1}$ Through prevention and regular dental visits, it is possible to prevent health problems in these musicians.

The construction of wind instruments plays an important role in the appearing of injuries of the stomatognathic system structures. Due to the construction of the mouthpiece, there are two types: brass and woodwind, which can be divided into single and double reeds. In the case of brass instruments (e.g. trumpet), the cup-shaped mouthpiece is applied to both lips during play (Fig. 1). When playing a single reed instrument (e.g. a saxophone), the mouthpiece is inserted into the mouth resting on the lower lip and pressing with the upper teeth (Fig. 2). When playing a woodwind instrument with a double reed (e.g. oboe), the mouthpiece is amortized on the teeth with an upper and lower lip (Fig. 3). ${ }^{1}$

Professional play requires continuous improvement of the skills and many hours of practice. Careless insertion or application of the mouthpiece to the mouth may cause dental injuries such as incisal damage, excessive attrition within the maxillary front teeth, fractures or even increased tooth mobility. Patients also complain of toothache that arises from the pressure of the mouthpiece on the

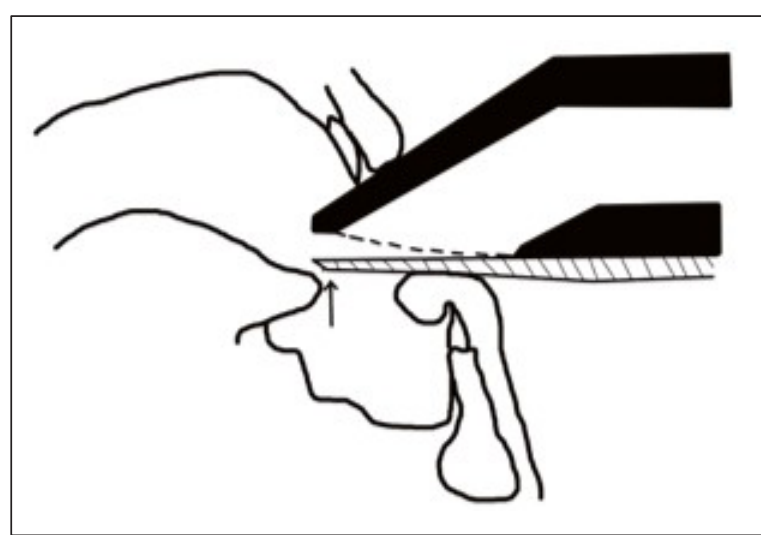

Fig. 2. Mouthpiece insertion method: single-reed woodwind instruments.

Ryc. 2. Metoda włożenia ustnika: instrumenty dęte drewniane jednostroikowe.

w obrębie twarzoczaszki, powstałych w wyniku gry na instrumencie dętym. ${ }^{1}$ Poprzez profilaktykę i regularne wizyty u lekarza dentysty możliwe jest zapobieganie powyższym problemom zdrowotnym u muzyków.

Istotną rolę w powstawaniu uszkodzeń struktur układu stomatognatycznego pełni konstrukcja instrumentów dętych. Ze względu na budowę ustnika wyróżnia się ich dwa rodzaje: blaszane oraz drewniane, które można podzielić na pojedynczo i podwójnostroikowe. W przypadku instrumentów dętych blaszanych (np. trąbka), ustnik o kształcie miseczki podczas gry przykładany jest do obu warg (ryc. 1). Grając na instrumencie dętym drewnianym jednostroikowym (np. saksofon) ustnik wkłada się do ust opierając na wardze dolnej i dociskając zębami górnymi (ryc. 2). Podczas gry na instrumencie dętym drewnianym podwójnostroikowym (np. obój) ustnik jest amortyzowany na zębach wargą górną i dolną (ryc. 3). ${ }^{1}$

Zawodowa gra wymaga ciągłego doskonalenia umiejętności i wielu godzin praktyki. Podczas nieostrożnego wprowadzania lub przykładania ustnika do ust, mogą powstać urazy zębów, takie jak: uszkodzenia brzegu siecznego, nadmierna atrycja w obrębie zębów przednich szczęki, złamania, czy nawet 


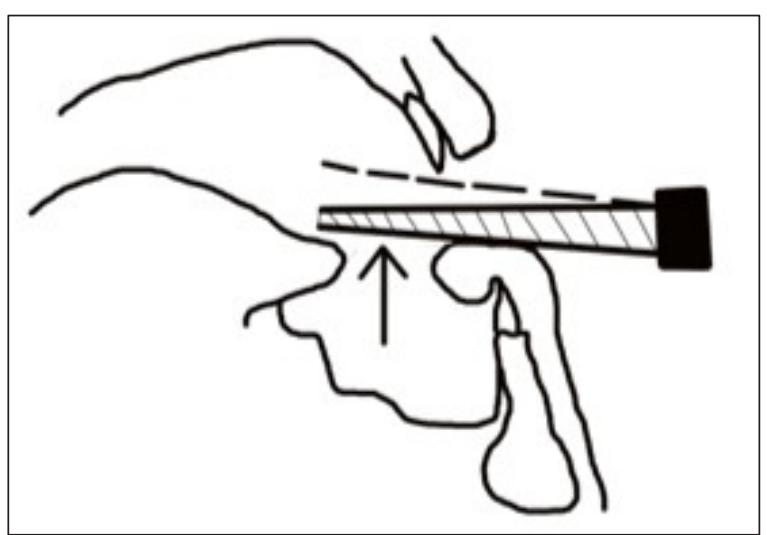

Fig. 3. Mouthpiece insertion method: double-reed woodwind instruments.

Ryc. 3. Metoda przyłożenia ustnika: instrumenty dęte drewniane podwójnostroikowe.

teeth when playing the instrument, and pain in the temporomandibular joints zone. ${ }^{2-5}$

Due to continuous exposure to the irritant factor, damage to the teeth and lips should be prevented when a wind instrument is played. For this reason, musicians should use mouthguards while playing, which will significantly reduce the number of complications. ${ }^{6-8}$

There are three types of the mouthguards: standard (available in three sizes), "boil and bite" type formed in the mouth after warming up, and customized prepared on the basis of an anatomical cast by a dentist in cooperation with a dental technician. ${ }^{9}$ In practice, musicians often place stickers on the mouthpiece, which absorb vibrations. The disadvantage of this solution, however, is that they wear out quickly and protect the mouthpiece from scratches rather than the teeth themselves from injury. ${ }^{10}$

\section{Aim}

The aim of the study was to assess the level of awareness of the use of mouthguards among musicians playing wind instruments, and to assess the incidence of damage within tooth tissues in the study group. zwiększona ruchomość zębów. Pacjenci skarżą się również na ból zębów, który powstaje przez nacisk ustnika na nie podczas gry na instrumencie oraz ból w obrębie stawów skroniowo-żuchwowych. ${ }^{2-5}$

Ze względu na ciągłą ekspozycję na czynnik drażniący należy zapobiegać uszkodzeniom zębów i warg podczas gry na instrumencie dętym. $\mathrm{Z}$ tego powodu muzycy podczas grania powinni używać ochraniaczy wewnątrzustnych, co znacznie zmniejszy liczbę powikłań. ${ }^{6-8}$

Wyróżnia się trzy rodzaje ochraniaczy wewnątrzustnych: standardowe (dostępne w 3 rozmiarach), typu ,boil and bite" formowane w jamie ustnej po rozgrzaniu oraz indywidualne przygotowywane na podstawie modelu anatomicznego przez lekarza dentystę we współpracy $\mathrm{z}$ technikiem dentystycznym. ${ }^{9} \mathrm{~W}$ praktyce muzycy często używają naklejek na ustnik, które amortyzują wibracje. Wadą takiego rozwiązania jest jednak to, że szybko się zużywają i w większym stopniu chronią ustnik przed zarysowaniami niż same zęby przed urazem. ${ }^{10}$

\section{Cel pracy}

Celem pracy była ocena świadomości muzyków w aspekcie uszkodzeń w obrębie tkanek twardych zębów spowodowanych grą na instrumentach dętych.

\section{Materiał i metoda}

Podczas badania przeprowadzono ankietę, kierowaną do osób związanych z grą na instrumentach dętych poprzez tematyczne fora internetowe oraz grupy zainteresowań w Polsce i za granicą. Grupę badaną stanowiło 1067 osób w tym 370 kobiet (35\%) i 697 mężczyzn (65\%) w wieku od 10 do 80 lat. Mediana wieku wynosiła 23 lat. Muzyków podzielono na dwie grupy w zależności od rodzaju instrumentu, na którym grają: drewniany (470 osób) i blaszany (597 osób). Ankiety zbierano metodą 


\section{Material and method}

During the study, a survey was conducted, addressed to people associated with playing wind instruments through thematic internet fora and interest groups all over the world. The study group consisted of 1067 people, including 370 women (35\%) and 697 men $(65 \%)$ aged 10 to 80 years. The mean age was 23 years. The musicians were divided into two groups depending on the type of instrument they play: woodwind (470 people) and brass (597 people). The surveys were collected using the CAWI (Computer-Assisted Web Interview) method in two language versions: Polish and English. The survey consisted of fifty questions (46 closed and 4 open). Among others, basic questions were asked regarding gender, age and type of instrument which the respondent played. Respondents were also asked about for how many years, how often and how many hours a day they play on average. They were also asked about the age at which the musicians had begun to play systematically, and whether playing a wind instrument was their daily occupation. Among the questions prepared for the respondents, thirteen directly related to the possibility of pain in the temporomandibular joint area. Respondents answered questions about the occurrence of the "classic triad" of symptoms such as pain in the ear area, limitation of jaw movements, patient's observations of clicks and jumping in the joint during playing. Questions were asked regarding ailments during jaw movements, as well as whether the respondents experienced muscle pain when chewing food. Information was collected on the occurrence of excessive tooth wear, teeth grinding, habitual clenching of teeth at night, the use of relaxation splints and intraoral protectors when playing a wind instrument; the frequency of headaches and muscle aches in the head and neck. Respondents answered whether they had used any form of warm-up
CAWI (Computer-Assisted Web Interview) w dwóch wersjach językowych - w języku polskim $\mathrm{i}$ angielskim. Ankieta składała się z 50 pytań (46 zamkniętych i 4 otwartych). Zadano między innymi podstawowe pytania dotyczące płci, wieku oraz rodzaju instrumentu, na którym grał ankietowany. Respondentom zadano również pytania od ilu lat, jak często i ile średnio godzin dziennie grają. Zapytano także o wiek, w którym muzycy rozpoczęli systematyczną grę, a także czy gra na instrumencie dętym stanowi ich wykonywany codziennie zawód. Wśród pytań przygotowanych dla ankietowanych, trzynaście odnosiło się bezpośrednio do możliwości występowania dolegliwości bólowych okolicy stawów skroniowo-żuchwowych. Respondenci odpowiedzieli na pytania dotyczące występowania „klasycznej triady” objawów, takich jak: ból okolicy ucha, ograniczenie ruchów żuchwy, zaobserwowania przez pacjenta trzasków i przeskakiwania $\mathrm{w}$ stawie podczas gry. Postawiono pytania dotyczące dolegliwości podczas ruchów żuchwą, jak również czy podczas żucia pokarmów ankietowani odczuwają bóle mięśniowe. Zebrano informacje na temat występowania nadmiernego starcia zębów, zgrzytania zębami, nawykowego zaciskania zębów w nocy, stosowania szyn relaksacyjnych oraz ochraniaczy wewnątrzustnych podczas gry na instrumencie dętym; częstości pojawiania się bólów głowy i bólów mięśniowych w obrębie głowy i szyi. Respondenci odpowiadali czy przed rozpoczęciem gry stosowali jakąkolwiek formę rozgrzewki, a także czy regularnie zgłaszali się na wizyty kontrolne do lekarza dentysty oraz czy zostali oni przez niego poinformowani o specyficznych problemach stomatologicznych, mogących wystąić u muzyków grających na instrumentach dętych oraz w jaki sposób postępować by nie dopuścić do powstania typowych dla tej grupy dolegliwości w obrębie układu stomatognatycznego.

Otrzymane dane, poddano analizie statystycznej przy użyciu testów statystycznych. 
before playing, and whether they regularly presented for follow-up visits at the dentist's, and whether they were informed by the dentist about specific dental problems that could occur when wind instruments are played and what to do to prevent the occurrence of ailments typical for this group within the stomatognathic system.

The obtained data were subjected to statistical analysis using statistical tests. Using the Pearson's Chi-square test and/or Pearson's Chi-square test with Yates continuity correction, relationships between gender and instrument groups were determined in relation to the manner of playing, the number of years, at what age, the frequency of practice, the number of hours of practice, whether the musician was a professional, warm-up, the occurrence of "classic triad symptoms", head and neck muscle pain, headache, as well as symptoms that may indicate bruxism: tooth wear, clenching, grinding, as well as the use of a relaxation splint at night.

In some cases, other indicators were additionallyused.TheMann-Whitney-Wilcoxon test was used to determine the relationship between the age at which the instrument started to be played and the relationship between the frequency of playing according to gender. The Wilcoxon test with continuity correction was also used to determine the gender dependence on the professionalism. In the analysis of the dependence of the length of practice on the occurrence of joint pain, as well as the length of the practice on the presence of limited mobility of the jaw, in addition to the Pearson Chisquare test, the Wilcoxon test with correction for continuity and the Kruskal-Wallis test were used. In the analysis of the relationship between the frequency of the practice and the occurrence of sound symptoms from the joints and the relationship between the frequency of the game and the occurrence of muscle pain, three tests were also used: the Pearson's Chi- square test,
Przy użyciu testu Pearson's Chi- kwadrat i/lub testu Pearson's Chi-kwadrat z poprawką na ciągłość Yatesa, określono zależności pomiędzy płcią oraz grupami instrumentów wobec: sposobu gry, liczby lat grania, wieku rozpoczęcia gry, częstości praktykowania, liczby godzin ćwiczeń gry, zawodowej gry, stosowania rozgrzewki, występowania „klasycznej triady objawów", bólu mięśni głowy i szyi, bólu głowy, a także objawów mogących świadczyć o bruksizmie: starcia zębów, zaciskania zębów, zgrzytania, jak również stosowania szyny relaksacyjnej w nocy.

W wybranych przypadkach dodatkowo stosowano inne wskaźniki. W określeniu zależności wieku rozpoczęcia gry na danym instrumencie oraz zależności częstości gry według płci zastosowano test Manna-WhitneyaWilcorona. Do ustalenia zależności gry zawodowej od płci zastosowano także test Wilcoxona z poprawką na ciągłość. W analizie zależności długości gry od występowania bólu stawu, a także długości gry od występowania ograniczonej ruchomości żuchwy zastosowano oprócz testu Pearsona Chi- kwadrat, test Wilcoxona $\mathrm{z}$ poprawką na ciągłość oraz test Kruskal-Wallis'a. W analizie zależności pomiędzy częstością gry a występowaniem objawów dźwiękowych ze strony stawów oraz zależności częstości gry a występowaniem bólu mięśniowego również zastosowano trzy testy: test Pearson's Chi- kwadrat, test Wilcoxona z poprawką na ciągłość oraz test KruskalWallis. We wszystkich przypadkach standardowo za próg istotności statystycznej przyjęto $p<0,05$. W analizie wieku respondentów określano rozkład kwartylowy, średnią, medianę, odchylenie standardowe oraz test normalności rozkładu Shapiro-Wilka.

\section{Wyniki}

W wyniku przeprowadzonych badań stwierdzono, że aż 86\% ankietowanych gra na 
the Wilcoxon test with correction for continuity, and the Kruskal-Wallis test. In all cases, the standard statistical significance threshold was $\mathrm{p}<0.05$. In the age analysis of the respondents, the quartile distribution, mean, median, modal distribution, standard deviation and the normality test of the Shapiro-Wilk distribution were determined.

\section{Results}

Based on the results of conducted survey $86 \%$ of respondents have played a wind instrument for at least 6 years. Among the whole research group $49.7 \%$ of respondents practise every day, $32.6 \%$ play for $1-2$ hours per day and $47.9 \%$ for 2-4 hours per day. Daily practice is more common for men than women ( $\mathrm{p}=0.01) .35 .61 \%$ of respondents claim that they attend regular dental visits every 6 months (Tab. 1). Yet, only 1 out of 8 musicians received specialist dental advice on the necessary increase in oral hygiene, risk of anterior teeth damage or suggestions of making mouthguards to protect teeth while playing wind instruments. Over $80 \%$ of respondents stated compliance with good oral hygiene rules, with a predominance of women $(\mathrm{p}=0.008)$.

As many as $27 \%$ of respondents reported excessive tooth mobility. Professional musicians reported statistically significant increase of tooth mobility $(p=0.0009)$ and more frequent anterior tooth damage caused by playing a wind instrument $(\mathrm{p}=0.03)$.

Table 2 presents the percentage of people with major symptoms of teeth damage depending on years of playing the instrument. Excessive tooth wear in the anterior region was reported by around $17 \%$ of respondents with predominance of women playing a wind instrument $(p=0.02)$ and professional musicians $(p=0.01)$. The awareness of the possibility of using mouthguards when playing a wind instrument was only 19\%. More often instrumencie co najmniej 6 lat. Spośród wszystkich ankietowanych $49,7 \%$ badanych ćwiczyło codziennie - $32,6 \%$ grało przez 1-2 godziny dziennie, a $47,9 \%$ przez $2-4$ h dziennie. Codziennie na instrumencie dętym ćwiczyło więcej mężczyzn niż kobiet $(\mathrm{p}=0,01)$. Wizyty u lekarza stomatologa regularnie co 6 miesięcy odbywało 35,61\% (tab. 1). Pomimo regularnych wizyt tylko 1 na 8 muzyków dostał specjalistyczne porady o niezbędnym zwiększeniu higieny jamy ustnej, możliwym uszkodzeniu zębów w odcinku przednim oraz zasugerowano mu wykonanie ochraniaczy wewnątrzustnych do grania na instrumencie dętym. U ponad $80 \%$ ankietowanych stwierdzono przestrzeganie właściwych zasad higieny jamy ustnej, $\mathrm{z}$ przewagą kobiet $(\mathrm{p}=0,008)$.

Aż 27\% respondentów zgłaszało nadmierną ruchomość zębów. Muzycy zawodowi zgłaszali istotnie statystycznie zwiększoną ruchomość zębów ( $p=0,0009)$ oraz częstsze uszkodzenia zębów w odcinku przednim spowodowanych grą na instrumencie dętym $(\mathrm{p}=0,03)$. Tabela 2 przedstawia odsetek osób z głównymi objawami dotyczącymi zębów w zależności od liczby lat grania na instrumencie. Nadmierne starcie zębów przednich ogółem zgłaszało około 17\% ankietowanych - częściej były to kobiety grające na instrumencie dętym $(p=0,02)$ oraz muzycy zawodowi $(\mathrm{p}=0,01)$. Świadomość o możliwości użytkowania ochraniaczy wewnątrzustnych podczas grania na instrumencie dętym miało tylko 19\% ankietowanych. Częściej byli to muzycy, którzy grali na instrumencie dętym drewnianym niż blaszanym ( $\mathrm{p}=0,008)$. Bardziej świadome były osoby grające na saksofonie i klarnecie ( $\mathrm{p}=0,01)$. Tylko $2 \%$ ankietowanych stosowało ochraniacze wewnątrzustne podczas gry na instrumencie dętym. Zdecydowanie najczęściej używali ich muzycy grający na instrumentach dętych drewnianych, takich jak saksofon $(\mathrm{p}=0,0001)$. Analizując poziom świadomości i użytkowanie ochraniaczy wewnątrzustnych 
Ta b le 1. Frequency of dental visits for individual groups of respondents

\begin{tabular}{|l|c|c|c|c|}
\hline & $\begin{array}{c}\text { More often than } \\
\text { once every six } \\
\text { months }\end{array}$ & $\begin{array}{c}\text { Once every six } \\
\text { months }\end{array}$ & Once a year & $\begin{array}{c}\text { Less than once } \\
\text { a year }\end{array}$ \\
\hline Women $(\mathrm{n}=370)$ & 29 & 136 & 104 & 101 \\
\hline Men $(\mathrm{n}=697)$ & 35 & 244 & 179 & 239 \\
\hline Woodwind $(\mathrm{n}=460)$ & 30 & 159 & 121 & 150 \\
\hline Brass $(\mathrm{n}=607)$ & 34 & 221 & 162 & 190 \\
\hline
\end{tabular}

Ta b le 2. Percentage of people with major dental symptoms depending on the number of years of playing the instrument

\begin{tabular}{|c|c|c|c|}
\hline \multirow[b]{2}{*}{ Years of playing } & \multicolumn{3}{|c|}{ Symptoms } \\
\hline & $\begin{array}{c}\text { Anterior tooth } \\
\text { damage during play } \\
[\% \text { (pers. })]\end{array}$ & $\begin{array}{c}\text { Presence of restora- } \\
\text { tions in anterior teeth } \\
[\% \text { (pers. })]\end{array}$ & $\begin{array}{c}\text { Excessive teeth } \\
\text { mobility } \\
[\% \text { (pers. })]\end{array}$ \\
\hline Up to 5 years $(n=149)$ & $3(5)$ & $35(5)$ & $36(5)$ \\
\hline $6-10$ years $(n=339)$ & $11(36)$ & $80(5)$ & $95(5)$ \\
\hline $11-20$ years $(n=340)$ & $10(34)$ & $90(5)$ & $102(5)$ \\
\hline $21-30$ years $(n=102)$ & $11(11)$ & $37(5)$ & $26(5)$ \\
\hline $31-40$ years $(n=54)$ & $13(7)$ & $13(5)$ & $12(5)$ \\
\hline More than 40 years $(n=83)$ & $7(6)$ & $24(5)$ & $19(5)$ \\
\hline
\end{tabular}

they were musicians who play a woodwind instrument rather than a brass instrument $(p=0.008)$. What is more, saxophone and clarinet players manifested higher awareness than other study participants $(\mathrm{p}=0.01)$. Only $2 \%$ of respondents used intraoral protectors when playing a wind instrument. In the study, musicians playing woodwind instruments, such as the saxophone, most often use protectors $(p=0.0001)$. Analyzing the level of awareness and use of mouthguards among musicians playing wind instruments, respondents were also asked about the type of intraoral protectors used during playing. The most popular was the wśród muzyków grających na instrumentach dętych zapytano również o rodzaj użytkowanych ochraniaczy wewnątrzustnych stosowanych podczas gry. Najpopularniejszym był ochraniacz indywidualny, najczęściej używany przez muzyków grających na instrumentach dętych drewnianych.

Zauważono istotną zależność między świadomością o możliwości stosowania ochraniaczy wewnątrzustnych a doświadczeniem. Muzycy grający dłużej na instrumencie dętym mają większą świadomość niż muzycy, którzy grają na nim krócej. 
custom-made mouthguard, most often used by musicians playing woodwind instruments.

A significant relationship was observed between the awareness of the possibility of using mouthguards and experience. Musicians who have played a wind instrument for a longer period of time are more conscious than musicians with shorter experience.

\section{Discussion}

Obtaining information about the method, duration of playing and hygiene habits is extremely important for the dentist to be able to advise patients on proper effective prophylaxis methods, as well as to employ appropriate treatment in case of the occurrence of symptoms within the stomatognathic system. ${ }^{11}$ The health problems of musicians, called occupational diseases, are caused by long-lasting regularly repeated practice, often positioning muscles in non-physiological postures. It may result in development of dangerous symptoms, which in extreme cases exclude professional musicians from work. Non-ergonomic positions adopted when playing a wind instrument, often cause loss of sensation and reduction of muscle coordination, needed to use the instrument properly. The prevention of pathological oral lesions in musicians, especially those playing professionally, is extremely important. ${ }^{12}$

In the study by Yeo DK. et al., the main oral problems of musicians were emphasised. They were divided into those regarding soft tissues and teeth. Muscle forces generated when playing wind instruments are higher than during physiological muscle work. While playing, the strength and duration of its action increase, pain and oral lesions such as ulceration or hyperkeratosis may occur, especially in the area of buccal and labial mucosa. Predisposing factors for the occurrence of oral mucosa lesions are braces, the presence of a diastema, missing teeth, non-carious lesions occurring at the

\section{Dyskusja}

Pozyskiwanie informacji o metodzie i czasie trwania gry oraz nawykach higienicznych jest niezmiernie ważne dla lekarza dentysty, aby móc zaproponować pacjentom prawidłową skuteczną profilaktykę, jak również dostosować odpowiednią formę leczenia w momencie wystąpienia objawów w obrębie układu stomatognatycznego. ${ }^{11}$ Problemy zdrowotne muzyków, nazywane chorobami zawodowymi, są spowodowane przez długotrwale powtarzane regularnie ćwiczenia, często wymagające utrzymania mięśni w niefizjologicznych pozycjach. Może to doprowadzić do rozwinięcia objawów, które w skrajnych przypadkach spowodują u zawodowych muzyków niezdolność do pracy. Nieergonomiczne pozycje przyjmowane podczas gry na instrumencie dętym, często powodują utratę czucia oraz zmniejszenie koordynacji mięśniowej, potrzebnej do prawidłowego korzystania z instrumentu. Niezmiernie ważna jest prewencja występowania patologicznych zmian w jamie ustnej muzyków, szczególnie grających zawodowo. ${ }^{12}$

W badaniach Yeo DK i wsp. wyróżniono główne problemy muzyków, które można spotkać w jamie ustnej. Podzielono je na te dotyczące tkanek miękkich oraz zębów. Siły mięśniowe generowane podczas grania na instrumentach dętych są wyższe niż podczas fizjologicznej pracy mięśni. Podczas grania, gdy wzrasta siła i czas jej działania, może wystąpić ból i zmiany o charakterze owrzodzeń, bądź hiperkeratozy, szczególnie w okolicy błony śluzowej policzków oraz warg. Czynnikami predysponującymi do występowania zmian na błonie śluzowej jamy ustnej są: stały aparat ortodontyczny, obecność diastemy, braki zębowe, ubytki niepróchnicowego pochodzenia występujące na brzegach siecznych, stłoczenia zębów. Autorzy wskazują konieczność wdrożenia odpowiednich działań terapeutycznych w celu zminimalizowania ryzyka pojawienia się tego 
incisal edges, crowded teeth. Authors indicate the need to implement appropriate therapeutic measures to minimize the risk of this type of problems. Among them, there are coating the elements of the orthodontic appliance with protecting wax, smoothing sharp edges of teeth and the instrument, restoration of missing teeth. In the case of excessive mobility of the teeth, it is recommended to use acrylic splint or prophylactic intraoral protectors. The second ones are also recommended if there is a risk of mechanical damage to the teeth. In the presence of complaints resulting from muscle fatigue, it is recommended to perform relaxation exercises, and if the patient complains of a reduced amount of saliva - salivary substitutes. ${ }^{11-16}$

Another problem associated with soft tissues is the outbreak of herpes virus infectin. When playing instruments, such a lesion is permanently traumatized, which slows healing, causes discomfort and increases the risk of its spreading in the oral cavity. ${ }^{1}$ An important factor, preventing the virus from spreading and favouring quick healing of lesions, is proper oral hygiene and instrument hygiene. Dentists should motivate patients to take care of hygiene and to pay attention to their individual needs. Despite frequent claims about proper oral care, patients are not aware of their individual needs. A dentist or a dental hygienist should correct bad habits, demonstrate good behavior, motivate and control whether the patient effectively cares for hygiene, to protect them from the consequences of bad habits. As for keeping the mouthpiece clean, the most common methods used by patients are rinsing with water, using soap and disinfection.

During the conversation with the patient, the doctor should inform them about proper methods of keeping the instrument clean and the consequences of these actions affecting the entire oral cavity.

Changes in the stomatognathic system caused by playing wind instruments can lead to typu problemów. Wśród nich między innymi wymieniane jest powlekanie elementów aparatu ortodontycznego woskiem zabezpieczającym, wygładzanie ostrych powierzchni zębów oraz instrumentu, odbudowa braków zębowych. W przypadku stwierdzenia nadmiernej ruchomości zębów zaleca się stosowanie szyn akrylowych czy profilaktycznie ochraniaczy wewnątrzustnych. Te drugie zalecane są również $\mathrm{w}$ sytuacji ryzyka powstania mechanicznego uszkodzenia zębów. W przypadku występowania dolegliwości wynikających ze zmęczenia mięśni zaleca się wykonywanie ćwiczeń relaksacyjnych, a jeśli pacjent skarży się na zmniejszoną ilość śliny - preparaty ślinozastępcze. ${ }^{11-16}$

Innym problemem dotyczącym tkanek miękkich jest występowanie wirusa opryszczki. Podczas gry na instrumentach zmiana taka jest stale traumatyzowana, co spowalnia gojenie, powoduje dyskomfort oraz zwiększa ryzyko rozprzestrzeniania się jej w obrębie jamy ustnej. ${ }^{1}$ Ważnym czynnikiem, zapobiegającym rozprzestrzenianiu się wirusa i sprzyjającym szybkiemu gojeniu zmiany jest prawidłowa higiena jamy ustnej, jak również instrumentu. Lekarz dentysta powinien motywować pacjenta do dbania o higienę i zwrócić uwage na jego indywidualne potrzeby. Mimo częstego przekonania o prawidłowym przeprowadzaniu czynności higienicznych, pacjenci nie zdają sobie sprawy ze swoich zindywidualizowanych potrzeb. Lekarz lub higienistka stomatologiczna powinni skorygować błędne zachowania, zademonstrować prawidłowe, motywować i kontrolować czy pacjent skutecznie dba o higienę, aby uchronić go przed konsekwencjami złych nawyków. Odnosząc się do utrzymywania czystości ustnika, najczęstszymi metodami stosowanymi przez pacjentów jest płukanie wodą, używanie mydła oraz dezynfekcja. Lekarz podczas rozmowy z pacjentem powinien poinformować o należytych metodach dbania o czystość instrumentu 
pathologies of hard dental tissues and even their loss. These are lesions typical of abrasion when the teeth have direct contact with a foreign body - a mouthpiece such as toothache, dental trauma, including avulsion. These lesions mainly affect incisors that come into contact with the mouthpiece. In musicians playing wind instruments, increased tooth mobility has also been observed in conjunction with the instrument positioning. Despite their increased mobility, the results of tests performed with Periotest were on the physiological scale of mobility. 3,4

In Engelman's research, the forces generated while playing wind instruments were measured and reached $500 \mathrm{gm}$, while the forces used during orthodontic treatment were on average 100 gm. ${ }^{13}$ This indicates the potential for tooth movement during intense practice. However, according to other authors, playing wind instruments does not affect the position of the anterior teeth or the development of malocclusion. There was a difference in the width of the upper arches among people playing wind instruments. The width was slightly reduced while maintaining the position of the teeth, despite the forces acting on them when playing. In addition, it has been observed that this force is mostly balanced, or the duration time is too short to cause significant changes within the stomatognathic system. ${ }^{14,15}$

In addition, musicians playing singlereed instruments produce more saliva, which leads to increasing the rate of dental calculus formation. ${ }^{16}$ However, the research has not confirmed that it leads to more frequent periodontal problems in this group of patients.

\section{Conclusion}

Musicians playing wind instruments constitute a specific group of patients that requires increasing awareness in terms of oraz następstwach tych działań wpływających na cała jamę ustną.

Zmiany w układzie stomatognatycznym wywołane graniem na instrumentach dętych, mogą prowadzić do patologii tkanek twardych zębów a nawet ich utraty. Są to zmiany o charakterze abrazji, gdy zęby mają kontakt z ciałem obcym- ustnikiem, bólu zębów, urazów zębów, w tym wybicia. Zmiany te dotyczą przede wszystkim zębów siecznych, które mają kontakt z ustnikiem podczas grania. U muzyków grających na instrumentach dętych, zaobserwowano również zwiększoną ruchomość zębów w obrębie kontaktu z ustnikiem danego instrumentu. Mimo zwiększenia ruchomości, wyniki badań przeprowadzonych Periotestem mieściły się w skali fizjologicznej ruchomości. ${ }^{3,4}$

W badaniach Engelmana zmierzono siły powstające podczas grania na instrumentach dętych, które sięgały 500gm, zaś siły używane podczas leczenia ortodontycznego wynoszą średnio $100 \mathrm{gm} .{ }^{13}$ Wskazuje to na możliwości przemieszczania zębów podczas intensywnego ćwiczenia. Jednakże według badań innych autorów granie na instrumentach dętych nie wpływa na pozycję zębów przednich ani na rozwój wady zgryzu. Zauważono różnicę w szerokości łuków górnych u osób grających na instrumentach dętych. Szerokość była nieznacznie mniejsza przy zachowanej pozycji zębów, mimo sił działających na nie podczas grania. Ponadto zaobserwowano, że siła ta jest zbalansowana lub trwa zbyt krótko, by powodować istotne zmiany w układzie stomatognatycznym. ${ }^{14,15}$

Muzycy grający na instrumentach jednostroikowych produkują więcej śliny, co w konsekwencji prowadzi do podwyższenia tempa tworzenia się kamienia nazębnego. ${ }^{16}$ Jednak pogląd, że prowadzi to do częstszych problemów periodontologicznych tej grupy pacjentów, nie został potwierdzony dalszymi badaniami. 
risk of damage occurrence in the area of the stomatognathic system and its prophylaxis.

Knowledge of dentists and dental hygienists in this field plays a major role in prevention and treatment of this group of patients with particular emphasis on oral hygiene and instrument hygiene, as well as an indication for the use of an intraoral protector.

\section{Wnioski}

Muzycy grający na instrumentach dętych są grupą pacjentów wymagającą zwiększenia poziomu świadomości w aspekcie ryzyka powstawania uszkodzeń w obrębie układu stomatognatycznego oraz ich zapobiegania.

Ważną rolę odgrywa wiedza lekarzy dentystów i higienistek odnośnie profilaktyki i leczenia tej grupy pacjentów ze szczególnym uwzględnieniem odpowiedniej higieny jamy ustnej oraz instrumentu, jak również wskazań do zastosowania ochraniacza wewnątrzustnego.

\section{References / Piśmiennictwo}

1. Yeo DK, Pham TP, Baker J, Porters SA: Specific orofacial problems experienced by musicians. Aust Dent J 2002; 47, 1: 2-11.

2. Gtowacka A, Matthews-Kozanecka M, Kawala M, Kawala B: The Impact of the Long-Term Playing of Musical Instruments on the Stomatognathic System - Review Adv Clin Exp Med 2014; 23, 1: 143-146.

3. Fijat D, Kaczmarczyk-Stachowska A, Knychalska-Karwan Z, Chomsztyn-Gajewska M, Ciesielska M, Gawrzewska B, Kwapińska $H$, Sendur A: Występowanie ubytków niepróchnicowego pochodzenia $\mathrm{w}$ populacji $\mathrm{w}$ wieku 15-80 lat w Krakowie. Czas Stomatol 2001; 54, 10: 636-641.

4. Fidecki M, Jodkowska E: Ruchomość zębów u muzyków grających na instrumentach dętych - doniesienie wstępne. Borgis - Nowa Stomatologia 2007; 2-3: 70-72.

5. Steinmetz A, Ridder PH, Methfessel $G$, Muche $B$ : Professional musicians with craniomandibular dysfunctions treated with oral splints. The Journal of Craniomandibular Practice 2009; 27, 4, 221-230.

6. Mańka-Malara K, Gawlak D, Euniewska J, Kostrzewa-Janicka J: Wykonawstwo klinicz- ne i laboratoryjne ochraniacza indywidualnego u pacjenta użytkującego stały aparat ortodontyczny - opis przypadku. Protet Stomatol 2014; 64, 5: 347-353.

7. Horvath $J$ : Playing (Less) Hurt: An Injury Prevention Guide for Musicians, Hal Leonard 2010; 234: 90.

8. Orenstein D: 7 Tips to Keep Your Lower Lip Pain-Free http://www.bestsaxophonewebsiteever.com/7-tips-to-keep-your-lower-lip-pain-free/

9. Gawlak D: Ocena użytkowania wewnątrzustnych ochraniaczy u młodzieży uprawiającej różne dyscypliny sportowe wstępne badania kliniczne, Czas Stomatol 2009; 62, 2: 141-148.

10. Orenstein D: Do You Need a Mouthpiece Patch? http://www.bestsaxophonewebsiteever.com/do-you-need-a-mouthpiece-patch/

11. Rodríguez-Lozano FJ, Sáez-Yuguero MR, Bermejo-Fenoll A: Orofacial Problems in Musicians: A Review of the Literature Medical Problems of Performing Artists 2011; 26, 3: 150-156.

12.Zuskin E, Schachter EN, Kolcić I, Polasek O, Mustajbegović J, Arumugam U: Health 
problems in musicians - a review, Acta Dermatovenerol Croat 2005; 13, 4: 247-251.

13. Engelman JA: Measurement of perioral pressures during playing of musical wind instruments. Am J Orthod 1965; 51: 856-864.

14. Grammatopoulos E: A study of the effects of playing a wind instrument on the occlusion (Master of Philosophy), University of Birmingham 2009.

15. Rindisbacher T, Hirschi $U$, Ingervall $B$, Geering A: Little influence on tooth position from playing a wind instrument. Angle Orthod 1989; 60: 223-228.

16. Bluj-Komarnitka K, Komarnitki I, OlczakKowalczyk D: Wind instruments and their influence on oral cavity: Systematic reviev. World J Dent 2014; 5, 3: 180-183.

Zaakceptowano do druku: 4.04.2020 r.

Adres autorów: 02-097 Warszawa, ul. Binieckiego 6.

CC Zarząd Główny PTS 2020. 